Acta Linguistica Petropolitana. 2021. Vol. 17.3. P. 43-66

DOI 10.30842/alp230657371734366

\title{
Диалектный словарь
}

\section{как лингвоаксиологический источник}

\section{В. М. Мокиенко}

Санкт-Петербургский государственный университет (Санкт-Петербург, Россия); mokienko40@mail.ru, v. mokienko@spbu.ru

\section{Т. Г. Никитина}

Псковский государственный университет (Псков, Россия); cambala2007@yandex.ru

Аннотация. В статье представлен опыт лексикографической разработки русских диалектных фразеологизмов и паремий в проектах, реализуемых авторами. Подчеркивается значимость для отечественной лексикографии разработанных составителями СРНГ принципов словарной репрезентации диалектизмов, показана преемственность и развитие идей основоположников отечественной диалектографии в новых словарных проектах. Особое внимание уделяется приемам интерпретации аксиологического компонента семантики фразеологизмов и паремий в диалектном словаре.

Ключевые слова: лексикография, диалектология, диалектография, лингвоаксиология, диалектизм, фразеологизм, паремия, Словарь русских народных говоров, фразеологический словарь, словарная статья, лексикографический параметр.

Благодарности. Исследование выполнено за счет гранта Российского научного фонда (проект № 20-18-00091 «Мир восточных славян в паремиологической интерпретации: аксиологические доминанты и их лингвокультурографическая репрезентация», реализуемый в Санкт-Петербургском государственном университете). 


\section{A dialect dictionary \\ as a linguoaxiological source}

\section{M. Mokienko}

St. Petersburg State University (St. Petersburg, Russia); mokienko40@mail.ru, v. mokienko@spbu.ru

\section{T. G. Nikitina}

Pskov State University (Pskov, Russia); cambala2007@yandex.ru

Abstract. The $100^{\text {th }}$ anniversary of the Institute for Linguistic Studies of the Russian Academy of Sciences is a propitious occasion to look back on Russian lexicography's track records, especially given that this academic science has been flourishing in Russia for over two centuries, its roots stretching back to ancient times. Initially, vocabulary studies focused on fixing and systemic description of folk words as defined by V. Dahl. Russian dialectal lexicography, now more than a century old, has a history of significant success in dictionary descriptions of Russian vocabulary and phraseology. The publication of the "Dictionary of Russian folk dialects" edited by F. P. Filin, F. P. Sorokoletov and S. A. Myznikov was a landmark event not only for Russian, but also for cross-linguistic lexicography and dialectology. This dictionary, as well as the dictionary projects the "Pskov regional dictionary" supervised by B. A. Larin, and the "Arkhangelsk regional dictionary" supervised by O. G. Getsova, gave a boost to dialectographic studies in practically all Russian regions. Notably, most new developments follow the lexicography principles of the "Dictionary of Russian folk dialects", its structure and vocabulary as a model and measure for vocabulary quality.

The article presents the experience of lexicographic processing of Russian dialect phraseological units and paremias in projects by its authors.

One example of this experience is a special consolidated dictionary of Russian dialect phraseology, "Polnyy frazeologicheskiy slovar russkikh narodnykh govorov" [Complete phraseological dictionary of Russian folk dialects], backed by a Russian Scientific Foundation grant (2017-2019) within the project "Mir vostochnykh slavyan $\mathrm{v}$ paremiologicheskoy interpretatsii: aksiologicheskiye dominanty i ikh lingvokulturograficheskaya reprezentatsiya" [The world of Eastern Slavs in paremiological interpretation: axiological dominants and their linguistic and cultural representation].

Working on this dictionary, we have expanded the phraseological vocabulary of the Dictionary of Russian folk dialects with materials from numerous fundamental Russian dialectal dictionaries, regional dictionaries, and small-scale local folklore collections including proverbs and sayings. Our dictionary accommodates modern 
views on phraseological units and proverbs as lexicographic description objects and applies new procedures for their objective linguistic and culturological commenting. In a bid to reflect the phraseology and paremiology dynamics in live speech, we have departed from the strictly differential principle of material selection. Nevertheless, the composition of the "Complete phraseological dictionary of Russian folk dialects" and the principles of the selection of phraseological units conform to those guiding the compilers of the "Dictionary of Russian folk dialects" in dealing with dialect vocabulary. The article accentuates the importance of the proposed principles for dictionary representation of dialecticisms, as well as the continuity and further development of ideas by Russian dialectography founders in new vocabulary projects. Particular attention is paid to the methods of interpreting the axiological component of phraseological units and paremias semantics applied in the dialect dictionary.

Keywords: lexicography, dialectology, dialectography, linguoaxiology, dialecticism, phraseological unit, paroimia, Dictionary of Russian folk dialects, phraseological dictionary, dictionary entry, lexicographic parameter.

\section{1. Введение}

100-летие ИЛИ РАН — значимый повод для подведения итогов отечественной лексикографии, тем более что эта отрасль академической науки в России процветает уже более двух столетий, а корни ее уходят в Древнюю Русь. Изначально словарное дело было устремлено к фиксации и системной характеристике народного слова в далевском его понимании. Неслучайно поэтому направление «Русская диалектная лексикография: история, теория и современная практика» становится все востребованнее в современной лексикографии. Этому направлению академической лексикографии также более века - века, ознаменованного весомыми успехами словарного описания русской лексики и фразеологии. Продолжая в минувшем столетии дело таких своих предшественников, как Я. К. Грот, А. А. Шахматов, А. И. Соболевский и др., Б. А. Ларин, Ф. П. Филин, Ф. П. Сороколетов, О. Г. Гецова, И. А. Оссовецкий, А. С. Герд, С. А. Мызников, Л. А. Ивашко, В. П. Строгова, А. И. Федоров, О. И. Блинова, В. В. Палагина, 
Н. С. Ганцовская, Е. В. Иванцова, Е. Б. Брысина, Л. Я. Костючук, 3. В. Сметанина, Т. В. Бахвалова, Л. З. Бояринова, И. А. Воробьёва, И. А. Подюков, Ф. Л. Скитова, В. А. Пащенко, Л. Е. Элиасов и многие «очарованные странники» диалектной фразеографии не только заложили ее материальную основу, но и воплотили свои идеи в полновесных словарях.

Выход в свет «Словаря русских народных говоров» [СРНГ] под редакцией Ф. П. Филина, Ф. П. Сороколетова и С. А. Мызникова стал знаковым событием не только отечественной, но и мировой лексикографии и диалектологии. Работа авторов СРНГ, так же как и словарные проекты «Псковского областного словаря» [ПОС] под руководством Б. А. Ларина и «Архангельского областного словаря» [АОС] под руководством О. Г. Гецовой, стала мощным стимулом для диалектографических разработок практически всех регионов России. И для большинства этих разработок принципы составления «Словаря русских народных говоров», его структура и словник стали лексикографическим образцом и мерилом словарного качества [Мокиенко 2011: 190].

\section{2. Развивая идеи основоположников жанра}

За 55 лет, прошедших с момента издания первого выпуска СРНГ, запас диалектизмов, в том числе фразеологических, в словарных картотеках значительно пополнился и продолжает пополняться. Диалектная фразеография и паремиография постепенно вырабатывали основы составления специализированных словарей диалектных устойчивых словосочетаний. Словари сибирской диалектной фразеологии, созданные под руководством проф. А. И. Федорова [СФС; ФСС], во многом опирались на академический опыт СРНГ уже потому, что их редактор был ленинградцем и вышел из группы составителей известного словаря под редакцией А. И. Молоткова. При составлении своего фразеологического словаря псковских говоров [СПП] мы исходили как из опыта составления «Псковского 
областного словаря» с его миллионной картотекой, так и из опыта СРНГ. Фразеологические словари других регионов России [Прокошева 1972; Прокошева 2002; Кобелева 2004; Ставшина 2008 и др.] также базируются на опыте разработки фразеологии ленинградскими / петербургскими лексикографами в СРНГ [Мокиенко 2011: 190-191].

Одним из обобщений этого опыта стал специальный сводный словарь русской диалектной фразеологии - «Полный фразеологический словарь русских народных говоров», поддержанный грантом РНФ (2017-2019 гг.) в проекте «Мир восточных славян в паремиологической интерпретации: аксиологические доминанты и их лингвокультурографическая репрезентация», реализуемом в Санкт-Петербургском государственном университете.

Работая над ПФСРНГ, мы расширили фразеологический словник СРНГ материалом многочисленных фундаментальных диалектных словарей русского языка, региональных словарей и собраний местного фольклора малого жанра, включающих пословицы и поговорки. Были учтены современные точки зрения на фразеологизм и пословицу как объект лексикографического описания, использованы новые модели их объективного лингвокультурологического комментирования. Было принято решение отступить от строго дифференциального принципа отбора материала, что позволило отразить динамику фразеологии и паремиологии в живой речи. Тем не менее состав ПФСРНГ и принципы отбора фразеологизмов соответствуют критериям, которыми руководствуются составители СРНГ по отношению к диалектной лексике [СРНГ 1: 5-7]. «... Какого бы значения и происхождения ни было слово, оно, как правило, будет включаться в Словарь лишь в том случае, если его употребляют не повсеместно, если оно не является словом современного литературного языка», - пишет во «Введении» к СРНГ Ф. П. Филин. Он делает существенную оговорку, особо, как кажется, актуальную по отношению к отбору фразеологических и паремиологических диалектизмов: «Во всех случаях, когда слово стоит на грани диалектной и общенародной лексики или когда невозможно определить, является ли слово диалектным или оно распространено 
повсеместно, вопрос решается в пользу помещения слова в Словаре» [СРНГ 1: 6]. Именно для фразеологизмов характерно расположение «на грани» диалектного и общенародного, и здесь лучше перейти эту грань в пользу смещения к общенародному, чем исключить выражения и паремии, актуальные для областной живой речи [Мокиенко 2011: 193]. К тому же многие диалектные фразеологизмы включают в себя лексические компоненты общенационального языка, например соматизмы. Составители СРНГ совершенно оправданно включают их в состав своего словаря, не комментируя исходное слово. Так, 1-е значение вокабулы Нога открывается типовой характеристикой «В сочетаниях», а затем под специальными графическими знаками даются фразеологизмы: 〈.. \ Залезать в рот с ногами. Быть бесцеремонным. Ворон., 1967. К холодным ногам (прийти). (Прийти) слишком поздно. Ворон. Молодой на ногу. Способный много, без устали ходить. Том., 1965. На богатую ногу. То же, что на всю ногу. Ряз. (На) боевую ногу стать. Начать хорошо, зажиточно жить. Кемер., 1964. На нашу ногу. По-нашему. Влад. На простую ногу. Ряз. На своих ногах. Самостоятельный. Ворон. На толстую ногу. То же, что на всю ногу. Дон., 1975. На тонкую ногу. Бедно. Дон., 1975. Сбрести на ноги. Выздороветь; окрепнуть. Новосиб., 1967. Спи, рука, спи, нога. а) Об удобной постели. б) Об очень спокойном, тихом человеке. По нижн. и средн. теч. р. Урал, 1976 [СРНГ 21: 261-263].

Легко заметить, что в ряды таких фразеологизмов органично «вклиниваются» и обороты, которые являются не столько диалектизмами в соответствии с принятым составителями дифференциальным подходом, сколько лишь вариантами общенародных устойчивых словосочетаний (ср. разговорное на широкую ногу и представленные выше на богатую ногу, на всю ногу, на боевую ногу) [Мокиенко 2011: 192]. В ПФСРНГ такого рода фразеологизмы описываются в единой макростатье, а их объединение под общим стержневым компонентом (как правило, существительным) позволяет увидеть и диапазон варьирования оборотов, и продуктивность их структурно-семантических моделей, и фраземообразовательную активность образного стержня [Мокиенко, Никитина 2018]. 


\section{3. Лингвоаксиология в лексикографическом формате}

В богатом материале СРНГ адекватно и детально отражены многие свойства русской народной речи. В зеркале Слова запечатлены многие реалии крестьянского быта, этнографические артефакты, мифологические представления - то есть все, что определяет лингвокультурологическую и ментальную составляющую традиционной России на всем ее широком пространстве. Собственно, СРНГ воспроизводит языковую картину нашего традиционного мира во всех еe ракурсах. Одной из важнейших составляющих этой картины является аксиологическая характеристика описываемых фактов. Базовым понятием аксиологии является ценность, система объективных и субъективных оценок, характеризующих окружающий мир и деятельность человека на оси глобальной бинарной оппозиции «Хорошо - Плохо». Ценностные ориентации определяют жизненную позицию человека, его коммуникативную стратегию, формируют его отношение к окружающему миру, который воспринимается «с точки зрения его ценностного характера - добра и зла, пользы и вреда и тому подобное, и это вторичное членение, обусловленное социально, - весьма сложным образом отражено в языковых структурах» [Арутюнова 1988: 45].

Аксиологическую направленность уже давно имеют этнолингвистические исследования группы Н. И. Толстого и С. М. Толстой, результатом которых стал фундаментальный словарь «Славянские древности. Этнолингвистический словарь» [Толстой (ред.)]. Именно в аксиологическом ключе под редакцией Е. Бартминьского созданы 5 капитальных томов ключевых концептов славянской лингвокультурологии - «Дом», «Европа», «Труд», «Свобода» и «Честь» [Bartmiński (red.)]. В некоторых из них для отдельных славянских языков используются и паремиологические материалы, что доказывает их общую аксиологическую эффективность. При этом специально фразеология и паремиология в разделах этих томов не рассматриваются, что дает новый импульс для фразеологических и паремиологических исследований. 
Накоплен и определенный опыт аксиологической характеристики отдельных блоков фразеологии (в широком смысле этого термина). Таков, например, цикл работ по лингвоаксиологии Л. К. Байрамовой: монография «Счастье и несчастье как ценность и антиценность во фразеологической парадигме» [Байрамова 2011в], «Аксиологический фразеологический словарь русского языка: Словарь ценностей и антиценностей» [Байрамова 2011б], «Аксиологический фразеологический словарь английского языка: Словарь ценностей и антиценностей» [Байрамова 2011а]. Все эти работы, хотя и разные по жанру и языковому материалу, объединены единой концепцией, основанной на философских работах о ценностях и выделении аксиологического параметра у языковых единиц. «В абсолютной ценностной пустоте невозможно никакое высказывание, невозможно само сознание», подчеркивал М. М. Бахтин [Бахтин 1986: 134]. Ценности, по его мнению, имеют конвенциональный характер, т. е. с определением главных ценностей в обществе существует согласие, ведь конвенциональные ценности - это «утвержденный контекст ценностей»: «совокупность ценностей, ценных не для того или иного индивидуума и в ту или иную эпоху, а для всего исторического человечества». Поэтому пословицы и поговорки, анализируемые в аксиологическом аспекте, имеют положительный или отрицательный вектор в зависимости от его корреляции с ценностью или антиценностью, которая может меняться.

Внимательно вчитываясь в 52 тома СРНГ, любой исследователь почерпнет ценнейшие материалы для воссоздания аксиологических оппозиций в народной фразеологии и паремиологии. Они образуют достаточно последовательную систему, позволяющую их структурировать. На материале фразеологии литературного языка такая попытка была нами осуществлена в синонимическом словаре [Бирих и др. 2009], на материале паремиологии - в идеографическом словаре пословиц [Мокиенко, Никитина 2011]. Сопоставляя такой материал (в основном на основе литературно-разговорной речи) с диалектной сокровищницей СРНГ, легко убедиться в неисчислимости народной фразеологии и паремиологии, воплощающей такие аксиологические оппозиции. Так, например, экспрессивная оппозиция 
«Глупый - Умный», являющая собой во многих языках семантическую универсалию [Diatschkow 1997], в синонимическом словаре [Бирих и др. 2009] представлена такими фразеологизмами:

ГЛУПЕЦ (ДУРАКК) * Голова садовая (еловая. Презр.; дубовая. Презр.; мякинная. Презр.). Неодобр.; дурья голова (башка)). Прост. неодобр.; баранья башка. Прост. презр.; голова [и] два yха. Прост. неодобр. Глупый, бестолковый человек (иногда говорится снисходительно).

Дубيина дубинной. Дуб дубом. Прост. презр.; дубина стоеросовая. Прост. презр.; болван болваном. Прост. презр.; балда балдой; болван стоеросовый. Прост. презр.; дундук дундуком. Прост. презр.; лопух лопухом. Прост. презр.; чурка (пень) с глазами. Грубо-прост. бран.; чурбанн чурбаном. Прост. презр. Совершенно, безнадежно глупый, тупой человек.

Доходит на третий день до кого. О несообразительном человеке, тугодуме.

Медный (толоконный) лоб. Книжн. презр. Бессмысленноупрямый, ограниченный человек, тупица [Бирих и др. 2009: 47].

ГЛУПЫЙ (ДУРАК) * Без царя в голове; нет царя в голове y кого. Неодобр.; опилки в голове $y$ кого. Презр.; отсутствие всякого присутствия $y$ кого. Шутл.; ум короток $у$ кого. Неодобр. О глупом, недалеком, бестолковом человеке.

Как дитя (как дитё. Прост.) маллое; хуже малого дитяти. $H e$ одобр. О наивном, бестолковом, глупом или впавшем в маразм человеке.

Мозги набекрень $y$ кого. Прост. ирон.; не все дома $y$ кого. Прост. ирон.; сдвиг по фазе у кого. Прост. ирон.; клёпок (одной клёпки) недостаёт у кого. Прост. ирон.; шариков (винтиков) не хватает у кого. Прост. ирон.; из-за угла мешком ударенный (стукнутый, прибитый). Прост. презр.; пыльным мешком ударенный. Прост. презр.; Богом убيтый (убيит). Устар. ирон. 
О человеке со странностями; о придурковатом и глупом человеке [Бирих и др. 2009: 48]

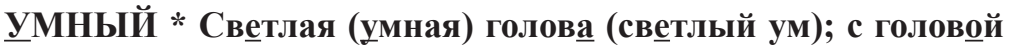
(с башкой. Прост.); человек большого ума; кладезь премудрости. Высок. и шутл.; ума не заниматьь кому. Об очень умном человеке.

Ума палата $y$ кого; голова [что] Дом Совтов у кого. Нов. иутл.; не голова - $[$ а] Дом Советов $y$ кого. Об очень умном, сведущем человеке.

Семй пядей во лбу. О чрезвычайно умном, мудром человеке.

Голова (котелок. Шутл.; черепушка. Шутл.) варит у кого. Прост. Об умном, сообразительном, находчивом человеке.

Умён как чёрт (как бес). Прост.; мудрый как царь Соломон. Устар. книжн. О чрезвычайно умном, мудром человеке [Бирих и др. 2009: 48, 212].

\section{4. Диалектизм как объект аксиологической словарной параметризации}

Погрузившись в глубины СРНГ и других диалектных источников, можно в разы увеличить «воплотителей» универсальной оппозиции «Глупый - Умный», например, по первому из этих противопоставленных понятий:

Деревеньская ографёна. Арх. Презр. О простом, необразованном или глупом, бестолковом человеке из деревни [АОС 11: 46].

Аноха Аноху да впряг в соху. Народн. Ирон. О двух глупцах, один из которых заставил другого что-л. делать. (В. И. Даль) [СРНГ 1: 261]. < Аноха - о простофиле, дураке, глупце. 
Аноха правведник (праведный). Влад. Ирон. (1846). О простофиле, дураке, глупце [СРНГ 1: 261].

Аноху строить. Прост. Сиб. Неодобр. Представляться простаком, глупцом [СРНГ 1: 261; СРНГ 42: 19; СФС: 17].

Бесполдённая Арина. Курск. Неодобр. (1840). Бестолковая, глупая, странная женщина [СРНГ 2: 273].

Афоня малохольный. Краснояр. (1967), Сиб. Неодобр. Неудачник [СФС: 17; ФСС: 8; СРНГ 17: 319]. < Малохольный-ненормальный, умственно неполноценный; глупый.

Бабба-дура. Пск. Презр. О глупой женщине [ПОС 19: 223].

Бабба рязанская. Волг. Прост., Пск. Ирон. О неловкой, рассеянной, глупой женщине [ПОС 1: 79; СПП: 15].

Деревеньская баба. Арх. Презр. О простом, необразованном или глупом, бестолковом человеке из деревни [АОС 11: 46].

Багун в голове $y$ кого. Смол. (1914). У кого-л. помрачение ума, кто-л. глуп [СРНГ 2: 37]. < Багун - глупость, помрачение ума.

Деревеньский балдёжник. Аpx. Презр. О простом, необразованном или глупом, бестолковом человеке из деревни [АОС 11: 46].

Балььки (балачки) не хват물 у кого. Лит. ССР. Неодобр. (1963). О глуповатом, не в своём уме человеке [СРНГ 2: 90]. < Балькастроевое бревно.

Дикая баракша. Сев.-Двин. Ирон. (1928). О крайне глупом человеке [СРНГ 2: 103]. < Баракша - то же.

Безглуздый баран. Курск. Бран. О крайне глупом человеке [СРНГ 2: 184]. < Безглуздый - бестолковый, безмозглый.

Дубовая башка. См. Дубовая голова (ГОЛОВА).

Дурна башка. Р. Урал. Бран. (1976). О глупом, тупом человеке [СРНГ 45: 302]. 
Пустая башк모 (головㅁ). См. Пустая голова (ГОЛОВА).

Таловая башка $y$ кого. Р. Урал. Бран. Ирон. (1976). О глупом человеке [СРНГ 43: 247]. < Ср. таловый. Омск. - сделанный из дерева, деревянный.

В башке толчеи нет у кого. Влад. Неодобр. (1905-1921). То же, что голова не варит (ГОЛОВА) [СРНГ 44: 218]. < Толчеясмышлёность, здравый ум.

Безлюдье полорукое. Влад. Бран. О плохих, неумелых и глупых людях [СРНГ 2: 192].

Ты на безмен, а он с аршином. Народн. Ирон. О глупом, бестолковом человеке. ДП: 449.

Ни бельмеса, ни разума, ни ума [y кого]. Сарат. (1959). О полном отсутствии разума у кого-л., глупом человеке [СРНГ 21: 212].

Бестолочью обтянуло кого. Кар. Кто-л. поглупел, начал плохо соображать [СРГК 1: 71].

Блазнота на уме $y$ кого. Смол. Неодобр. (1914). О человеке, думающем о чем-л. несерьёзном, глупом [СРНГ 3: 15]. < Блазнота - глупость.

У Бога телёнка съел. 1. Прост. Шутл.-ирон. О простоватом, глуповатом, наивном человеке [Соколова 2009: 58, 334]. 2. Р. Урал. (1976). О человеке, сделавшем что-л. нелепое, удивительное [СРНГ 43: 108, 348].

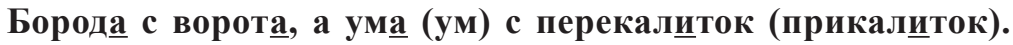
Курск., Новг. Неодобр. О легкомысленном, глупом немолодом человеке [СРНГ 31: 237]. < Перекалиток - пристройка для хозяйственных надобностей. Прикалиток-небольшая дверь в воротах, калитка. Борода с ворота, а ума с перекалиток нет. $H u$ жегор. (1852). То же [СРНГ 26: 117].

С бусорью. Калуж. Неодобр. или шутл.-ирон. О глуповатом, несообразительном человеке [СРНГ 3: 238]. 
Бусарь в голове $y$ кого. Ворон., Дон., Калуж., Орл. Неодобр. О глупом человеке [СРНГ 3: 303]. < Бусарь - глупость, дурь.

С бусарью. Брян., Ворон., Дон. (1874), Калуж., Курск. (1850), Ставроп., Тамб., Тул. Неодобр. То же, что с бусырью 1. [СРНГ 3: 303].

Бусор в голове $y$ кого. Калуж. Неодобр. (1892). О глупом, глуповатом человеке [СРНГ 3: 307]. < Бусор - глупость, дурь.

С бусором. Калуж. Неодобр. (1892). То же, что с бусырью 1. (БУСЫРЬ). [СРНГ 3: 307].

С бусырью (бусорью). 1. Волг., Дон. (1874), Енис., Сарат. (1858), Сиб., Тул. Неодобр. или Шутл.-ирон. О глуповатом, несообразительном человеке [СФС: 162; ФСС: 18]. 2. Курск. (1947-1953), Орл., Сиб. Неодобр. О грубом, сердитом человеке [СРНГ 3: 303; СФС: 162; ФСС: 18]. 3. Дон., Сиб. Неодобр. О высокомерном человеке [СДГ 1: 50]. < Бусырь - глупость, дурь.

С бусырью в голове. Брян. Неодобр. То же, что с бусырью 1. [СРНГ 3: 308].

С бусью. Ворон., Курск. Неодобр. То же, что с бусырью 1. [СРНГ 3: 308]. < Бусь - глупость, дурь.

Не смыслит Вавила ни уха ни рыла. Народн. Неодобр. О глупом, несообразительном человеке [ДП: 455].

Ваньжа сук рубит, а сам на ём сидит. Свердл. Ирон. (1964). О действиях глупого человека, который, поступая необдуманно, наносит себе непоправимый вред [СРНГ 4: 36]. < Ванньжаглупый, несообразительный человек, простофиля.

Ванюша кудрявый. См. Ваня кудрявый (ВАНЯ).

Тухла варка. Р. Урал. Бран. (1976). О глупом, тупом человеке [СРНГ 45: 302].

Аксиологическая палитра пословиц, естественно, несколько отличается от фразеологической, поскольку систему оценок здесь диктует 
дидактическая, морально-нравственная семантика. Тем не менее основные аксиологические доминанты и здесь обнаруживают определенную перекличку, хотя языковые способы квалификации оппозиций «Добро - Зло», «Ум - Глупость», «Правда - Ложь» и т. п. различны по определению. И здесь материалы СРНГ представляют исключительную ценность. Составители последовательно, на протяжении всех 50 томов, выдерживают строгую маргинальную линию между пословицами и поговорками (resp. фразеологизмами). Она четко маркируется графически: фразеологизмы обозначаются прямым полужирным шрифтом, в то время как пословицы - курсивом и с пометой в скобках: (пословица). Более того: если фразеологизмы-поговорки, как выше говорилось, нередко составляют обильные гнезда вокруг компонентов общелитературного языка — голова, нога, рука и под., то пословицы под такими компонентами даются лишь как исключение. Вот один из редких примеров - компонент Репа, где введение пословиц предваряется фразой «В поговорках и пословицах»:

Шуйск. Влад. Голодному Федоту и репа в охоту; Капуста да репа брюху не крепа;

Помор. Арх., 1885. Репа брюху не крепа;

Онеж. КАССР, 1933. Репа да горох сеются для воров;

Холмог. Арх., 1907. Хоть репа без костей, да и на той кора (горькая) [СРНГ 35: 65].

Как видим, даже в таких случаях аксиологическая составляющая просматривается и по этим паремиям легко реконструируется оценка репы в традиционном русском крестьянском быту.

Ср. также «одиночные» размещения пословиц под недифференциальной лексикой, которые, правда, в большинстве случаев оправданы либо региональной семантикой, либо вхождением в состав фразеологизмов:

Больше ремесла, больше и зльидней под ремесло 'искусство, умение' [СРНГ 35: 55]. 
Не рок головы ищет, сама голова на рок идёт под рок 'неизбежное несчастье, несчастная судьба, участь’ [СРНГ 35: 168].

Ловит волк роковую овиу под роковой 'обречённый на гибель' [СРНГ 35: 169].

Петрозав. Олон. Участи-талану не пришить к сарафану под участь 'счастливая судьба' [СРНГ 48: 314$]$.

Смол. Не учи учёного есть хлеба печёного под учёный [СРНГ 48: 316-317].

Кашин. Твер. За учёного двух неучёных дают под учёный [СРНГ 48: 316-317].

Учи жену без детей, а детей без людей под учить (учить жену) ‘бить' [СРНГ 48: 325].

Опоч. Пск., 1852. Лебед. Тамб., 1850. Скажешь с уха на ухо-узнают с угла на угол под ухо (с уха на ухо (говорить) 'говорить тихо, таиться') [СРНГ 48: 275].

Твер. Минус. Енис. Дверь добро с ушами, а храмина с очами под yxo [СРНГ 48: 278].

Вдовий обиход не уход под уход 'уборка, наведение порядка' [СРНГ 48: 285].

Р. Урал. Последняя рука хуже дурака под рука 'удар по мячу (при игре в лапту), право такого удара’ [СРНГ 35: 242].

Николаев. Самар., 1853. Добрая жена дом сбережёт, а плохаярукавом разнесёт под рукавом разнести 'промотать, разорить (состояние, хозяйство)' [СРНГ 35: 245].

В основном же составители оправданно помещают пословичный материал под дифференциальной лексемой, иллюстрируя тем самым классические диалектизмы, напр.:

фольк. На летячем камне и мох не растёт под летячий 'такой, который летит, летящий [СРНГ 17: 27]. 
Смол. Чиста, личиста, да и говорить речиста под личистый 'красивый лицом' [СРНГ 17: 88].

Волог. Не солоду, не хмелю да лишо бух во чан (пословица) под лишо 'лишь' [СРНГ 17: 90].

Собака и в море лохчет, да не всё же выпьет под лохтать 'глотать, хлебать с жадностью, помногу' [СРНГ 17: 164].

Перм. Ночь почуй, другу ночуй, третью люлюй под люлить 'укачивать ребёнка' [СРНГ 17: 245].

Кирилл. Новг., 1849. Знают Фому и в регозинном ряду под регозинный (знач.?) [СРНГ 35: 13].

Мурман., 1979. Из звонка [морская утка] уха тонка под звонок ‘суп из дичи' [СРНГ 48: 234].

Влад. Друг всем макарам, а ухи не видал под макар 'завзятый рыболов’ [СРНГ 17: 308].

Низ. Печора, 2005. Без учи в попь не ставят под уча 'учеба, обучение' [СРНГ 48: 312].

Волог., 1898. Рядись - не торопись, на прибавку не надейся под рядиться 'торговаться, условливаться о цене, споря друг с другом, стараться купить что-л. подешевле' [СРНГ 35: 341].

Олон., 1885-1898. Однажды ряжено-одна и руга 'Раз условились о цене, не следует назначать другую цену’, где руга ‘плата пастуху' [СРНГ 35: 229] и т. п.

И в таких паремиях оценка различных явлений крестьянской жизни выражена прозрачно и образно; к каждой из таких пословиц легко подобрать аксиологический комментарий.

Следует ценить гостеприимство, избегая излишне частых визитов к друзьям: Где любят, не части (посещеньем), а где нет, реди под редить 'появляться редко, не часто' [СРНГ 35: 18]; Смол., 19051921. Иде любють, не учашай, а иде не любють, ноги не накладай под учащатьь ‘2. часто ходить куда-л.’ [СРНГ 48: 314]. 
Преступление наказуемо: Тул., 1820. Злое ремесло на рель занесло под рель 'виселица' [СРНГ 35: 50]; Ряз. Село для дворов, а рель для воров [СРНГ 35: 50].

Предостережение перед присвоением чужого: Ворон. Чужсй кус фатишь, да рубль платишь, а два-не разделаешься под фатить ‘схватывать, хватать' [СРНГ 49: 71].

Жизнь в тесноте лучше, чем раздоры: Нижегор., 1840. Не возьлёт теснота, а возьмёт лихота под лихота 'нелады, ссора' [СРНГ 17: 83].

Лицемерие осуждается: Яросл. Правду говорит пословица, что лищемёриики Богу молятся, а чертям веруют под лицемёрщик 'лицемер' [СРНГ 17: 83].

Осуждаются люди, живущие за счет других: Пск., Смол. Немного работников да много ломотников под ломотник 'один из тех, кто питается вместе с кем-либо за общим столом; едок' [СРНГ 17: 124].

Осуждается скопидомство и крохоборство: Волог., 1898. Крохи собирает, а ломотье теряет под ломотье 'ломти (хлеба)' [СРНГ 17: 124].

Осуждается хвастовство: фольк. Фасть обедать не дасть под фасть 'хвастовство' [СРНГ 49: 71].

Осуждается пьянство: Волог. Пьяному море по колено, а львка по уши под лывка 'лужица' [СРНГ 17: 218].

Необходимо остерегаться обманщиков: Олон. Мани всякому даны, т. е. «обмануть всякий может» под мана 'обман' [СРНГ 17: 354].

Предупреждение против нарушения законов и установленного порядка: Недолго той земле стоять, где учнут уставы ломать под учинать 'начинать' [СРНГ 48: 321].

В ряде случаев аксиологическая маркировка выражена паремиями со всей прямолинейностью народной речи: Арзамасиы гусятники, луковники, малеваны под малеван 'иконописец' [СРНГ 17: 320]; Саночки-малеваночки: сел на них да поехал в них под малеваночка ‘о том, что ярко, красиво раскрашено’ [СРНГ 17: 320].

Аксиологический потенциал паремий с именами собственными недавно был исследован М. Л. Ковшовой на материале загадок [Ковшова 2019]. Хотя Ф. П. Филин не включал этот разряд слов в корпус Словаря, но тем не менее имена собственные, представляющие культурологическую ценность как компоненты паремий, нередко 
получают отражение в СРНГ. В нашем ПФСРНГ мы продолжаем эту традицию, расширяя ряд «ономастических» фразеологизмов [Мокиенко 2011: 193], напр.:

МАКАР * Где Макар быков не пас. Кар. Шутл. То же, что куда Макар телят не гонял [СРГК 1: 152].

Загнать туда, куда Макар телят не гонял. Народн. Расправиться с кем-л., строго наказать кого-л. [Соколова 2009: 571].

Куда Макар телят не гонял. Ленингр., Пск., Разг. Шутл. Очень далеко, в отдалённое место (послать, сослать, отправить) [СПП: 51].

Тутушка Макарp! Со подушки упал, А дедушка увидал, Макарушку поднимал. Нижегор. Ирон. (1894). Поговорка о неудачливом Макаре [СРНГ 45: 299]. < Тутушка — в этом месте, здесь.

Узнать, куда Макар телт гонял. Народн. Подвергнуться строгому наказанию, расправе [Соколова 2009: 572].

На бедного Макара все шишшки валятся. Прост. Чем беднее и несчастнее человек, тем больше бед и неудач он испытывает [ДП: 60, 147, 706].

Не Макара родить. Горьк. Шутл. (1973). О каком-л. несложном деле, не составляющем большого труда кому-л. [СРНГ 35: 137].

Макаром смотреть. Ряз. Неодобр. О лицемерном, притворяющемся человеке. < Макар - лицемер, плут [СРНГ 17: 308].

Особенно уместна фиксация имен собственных в пословицах. Так, в СРНГ (36) имя Савва не фиксируется. В раздел диалектизмов-пословиц ПФСРНГ оно будет тем не менее включено, ибо такие пословицы по всем параметрам соответствует принципу дифференциального отбора диалектного материала [Мокиенко 2011: 194]:

\section{CÁBBA}

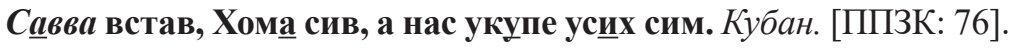




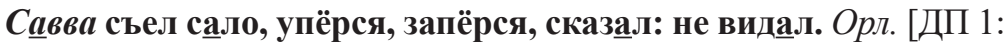
$160]$.

От С $\underline{a b b l ~ с л а в ы, ~ а ~ о т ~ П е р ш и ~ ч е с т и . ~ П с к . ~[С П П: ~ 139] . ~}$

Как видим, русская диалектная фразеология, органически инкрустированная в СРНГ, воспроизводит всю яркую палитру аксиологически ориентированной русской образной речи. Почти полный ареальный охват, широкая семантическая и стилистическая амплитуда, вариантное многообразие и воспроизведение традиционных русских реалий с полным правом делают словарь, созданный лексикографами ИЛИ РАН, не только лексическим, но и фразеологическим тезаурусом.

\section{5. Заключение}

Анализ фразеологического материала, подвергнутого последовательному описанию в СРНГ, демонстрирует высокое мастерство его составителей и редакторов. Неслучайно это мастерство маркировано печатью академической лексикографии. Ведь со времени основания Императорской Российской Академии по указу Екатерины II в сентябре 1783 года главной целью ее сотрудников было изучение русского языка и словесности. Эта цель сохранила свою заостренность и после соединения Императорской Академии с Академией наук в виде ее Второго отделения. И с екатерининских времен задача новой академии, сформулированная как «очищение и обогащение» русского языка, неуклонно выполнялась разными поколениями лексикографов. Во многом процесс «обогащения» был успешен благодаря неистощимым источникам народной речи. И первый (гнездовой) шеститомный академический словарь 1784-1789 гг., и второй (алфавитный) академический словарь 1806-1822 гг., и все последующие толковые справочники вплоть до новейшего БАСа, рожденные в лоне Академии наук, черпали материал из этого источника. Словарь русского языка, составленный Вторым отделением Императорской Академии 
наук (1891-1930) и комиссией по русскому языку Академии наук СССР (1930-1937) под редакцией Я. К. Грота, А. А. Шахматова, В. И. Чернышёва, Л. В. Щербы и др., был попыткой максимально полного синтеза литературно-книжной и народной стихии русской речи. СРНГ, задуманный Ф. П. Филиным и продолженный под редакцией Ф. П. Сороколетова и С. А. Мызникова многолетним самоотверженным трудом когорты самых опытных диалектографов ИЛИ РАН, сделал объектом описания именно народную речь во всем ее аксиологическом многоцветье. И мы, фразеологи, ожидая выхода 53-го тома этого диалектного тезауруса, постоянно обращаемся к нему за новыми идеями и лексикографическими проектами. Обращаемся, поздравляя наших коллег из ИЛИ РАН со столетним юбилеем.

\section{Литература}

Арутюнова 1988 - Н. Д. Арутюнова. Типы языковых значений: Оценка. Событие. Факт. М.: Наука, 1988.

Байрамова 2011a - Л. К. Байрамова. Аксиологический фразеологический словарь английского языка: Словарь ценностей и антиценностей. Казань: Центр инновационных технологий, 2011.

Байрамова 20116 - Л. К. Байрамова. Аксиологический фразеологический словарь русского языка: Словарь ценностей и антиценностей. Казань: Центр инновационных технологий, 2011.

Байрамова 2011в - Л. К. Байрамова. Счастье и несчастье как ценность и антиценность во фразеологической парадигме. Казань: Центр инновационных технологий, 2011.

Бахтин 1986 - М. М. Бахтин. Эстетика словесного творчества. М.: Искусство, 1986.

Бирих и др. 2009 - А. К. Бирих, В. М. Мокиенко, Л. И. Степанова. Словарь фразеологических синонимов русского языка. М.: Аст, 2009.

Кобелева 2004 - И. А. Кобелева. Фразеологический словарь русских говоров Республики Коми. Сыктывкар: Сыктывкарский государственный университет, 2004.

Ковшова 2019-М. Л. Ковшова. К вопросу об аксиологической модальности загадок: что на свете всех милее? // Н. А. Купина (отв. ред.). Аксиологические аспекты современных филологических исследований: тез. докл. Междунар. науч. конф. Екатеринбург: Ажур, 2019. С. 29-33. 
Мокиенко 2011 - В. М. Мокиенко. Проект «Фразеологического словаря русских народных говоров» // Проблемы истории, филологии, культуры. 2011. № 3 (33). С. 190-198.

Мокиенко, Никитина 2011 - В. М. Мокиенко, Т. Г. Никитина. Народная мудрость. Русские пословицы. М.: ОЛМА Медиа Групп, 2011.

Мокиенко, Никитина 2018 - В. М. Мокиенко, Т. Г. Никитина. К концепции полного словаря народной фразеологии: проблемы макроструктурирования // Вопросы лексикографии. 2018. № 14. С. 80-106.

Прокошева 1972 - К. Н. Прокошева. Материалы для фразеологического словаря говоров Северного Прикамья. Пермь: б. и., 1972.

Прокошева 2002 - К. Н. Прокошева. Фразеологический словарь пермских говоров. Пермь: ПГПУ, 2002.

Ставшина 2008 (сост.) - Н. А. Ставшина (сост.). Фразеологический словарь русских говоров Нижней Печоры: [в 2 т.]. СПб.: Наука, 2008.

Толстой (ред.) 1995-2014-Н. И. Толстой (ред.). Славянские древности. Этнолингвистический словарь: в 5 т. / РАН. Институт славяноведения и балканистики. М.: Международные отношения, 1995-2014.

Bartmiński (red.) 2015-2019 — Je. Bartmiński (red.). Lexicon aksjologiczny Słowian i ich sąsiadów. T. 1-5. Lublin; Warszawa: wydawnictwo Uniwersytetu Marii Curie-Skłodowskiej, 2015-2019.

Diatschkow 1997 - A. Diatschkow. Untursuchungen zur konfrontativen Phraseologie der deutschen und der russischen Gegenwartssprache am Beispiel der semantischen Felder der menschlichen Intelligenz mit der alldemeinen Bedeutung "Dummheit / Klugheit" und "глуnость / yм". Dissertation zur Erlangung des akademischen Grades doctor Philosophiae der Philosophischen Fakultät der ErnstMoritz-Arndt-Universität Greifswald. Greifswald: Ernst-Moritz-Arndt-Universität Greifswald, 1997.

\section{Источники}

АОС - О. Г. Гецова (ред.). Архангельский областной словарь. Вып. 1-20. М.: МГУ; Наука, 1980-2019.

ДП-В. И. Даль. Пословицы русского народа. М.: Художественная литература, 1957.

ДП 1 - В. И. Даль. Пословицы русского народа. Изд. 3-е. В 2 т. Т. 1. М.: Художественная литература, 1984.

ПОС - Псковский областной словарь с историческими данными. Вып. 1-26. Л.; СПб.: Изд-во ЛГУ; СПбГУ, 1967-2016. 
ППЗК - Л. Б. Мартыненко, И. В. Уварова (сост.); Л. А. Степанов (ред.). Пословицы, поговорки и загадки Кубани. Краснодар: Кубанский государственный университет, 2002.

СДГ-Словарь русских донских говоров. Т. 1-3. Ростов-на-Дону: Ростовский государственный университет, 1975-1976.

Соколова 2009 - М. И. Соколова. Народная мудрость. Пословицы и поговорки. Новосибирск: Офсет, 2009.

СПП 2001 - В. М. Мокиенко, Т. Г. Никитина (сост.); Л. А. Ивашко (ред.). Словарь псковских пословиц и поговорок. СПб.: Норинт, 2001.

СРГК - А. С. Герд (ред.). Словарь русских говоров Карелии и сопредельных областей. Вып. 1-6. СПб.: СПбГУ, 1994-2005.

СРНГ - Ф. П. Филин, Ф. П. Сороколетов, С. А. Мызников (ред.). Словарь русских народных говоров. Вып. 1-52. М.; Л.; СПб.: Наука, 1965-2021.

СФС - Н. Т. Бухарева, А. И. Федоров (сост.). Словарь фразеологизмов и иных устойчивых словосочетаний русских говоров Сибири. Новосибирск: Наука, 1977.

ФСС - Л. Г. Панин, Л. В. Петропавловская, А. И. Постнова, А. И. Федоров (сост.); А. И. Федоров (ред.). Фразеологический словарь русских говоров Сибири. Новосибирск: Наука, 1983.

\section{References}

Arutyunova 1988 - N. D. Arutyunova. Tipy yazykovykh znacheniy: Otsenka. Sobytiye. Fakt [Types of linguistic meanings: Evaluation. Event. Fact]. Moscow: Nauka, 1988.

Bakhtin 1986 - M. M. Bakhtin. Estetika slovesnogo tvorchestva [Aesthetics of verbal creativity]. Moscow: Iskusstvo, 1986.

Bartmiński (ed.) 2015-2019- Je. Bartmiński (ed.). Lexicon aksjologiczny Słowian i ich sasiadów. [Axiological lexicon of Slavs and their neighbors]. T. 1-5. Lublin;

Warszawa: wydawnictwo Uniwersytetu Marii Curie-Skłodowskiej, 2015-2019.

Bayramova 2011a — L. K. Bayramova. Aksiologicheskiy frazeologicheskiy slovar angliyskogo yazyka: Slovar tsennostey $i$ antitsennostey [Axiological phraseological dictionary of the English language: Dictionary of values and anti-values]. Kazan: Center for innovative technologies, 2011.

Bayramova 2011b - L. K. Bayramova. Aksiologicheskiy frazeologicheskiy slovar russkogo yazyka: Slovar tsennostey i antitsennostey [Axiological phraseological dictionary of the Russian language: Dictionary of values and anti-values]. Kazan: Center for innovative technologies, 2011. 
Bayramova 2011c - L. K. Bayramova. Schastye i neschastye kak tsennost $i$ antitsennost vo frazeologicheskoy paradigme [Happiness and misery as value and anti-value in the phraseological paradigm]. Kazan: Center for innovative technologies, 2011.

Birikh et al. 2009 - A. K. Birikh, V. M. Mokiyenko, L. I. Stepanova. Slovar frazeologicheskikh sinonimov russkogo yazyka [Dictionary of phraseological synonyms of the Russian language]. Moscow: AST, 2009.

Diatschkow 1997 - A. Diatschkow. Untersuchungen zur konfrontativen Phraseologie der deutschen und der russischen Gegenwartssprache am Beispiel der semantischen Felder der menschlichen Intelligenz mit der alldemeinen Bedeutung “Dummheit/Klugheit” und “глупость / ум”. Dissertation zur Erlangung des akademischen Grades doctor Philosophiae der Philosophischen Fakultät der ErnstMoritz-Arndt-Universität Greifswald. Greifswald: Ernst-Moritz-Arndt-Universität Greifswald, 1997.

Kobeleva 2004 - I. A. Kobeleva. Frazeologicheskiy slovar russkikh govorov Respubliki Komi [Phraseological dictionary of Russian dialects of the Komi Republic]. Syktyvkar: Syktyvkar State University Press, 2004.

Kovshova 2019 - M. L. Kovshova. K voprosu ob aksiologicheskoy modalnosti zagadok: chto na svete vsekh mileye? [On the axiological modality of riddles: what is the cutest thing in the world?]. N. F. Kupina (ed.). Aksiologicheskiye aspekty sovremennykh filologicheskikh issledovaniy: Tezisy dokladov Mezhdunarodnoy nauchnoy konferentsii [Axiological aspects of modern philological research: abstracts of reports of an international scientific conference]. Ekaterinburg: Azhur, 2019. P. 29-33.

Mokiyenko 2011 — V. M. Mokiyenko. Proyekt «Frazeologicheskogo slovarya russkikh narodnykh govorov» [Project of the "Phraseological dictionary of Russian folk dialects"]. Problemy Istorii, filologii, kultury. 2011. No. 3 (33). P. 190-198. Mokiyenko, Nikitina 2011 - V. M. Mokiyenko, T. G. Nikitina. Narodnaya mudrost. Russkiye poslovitsy [Folk wisdom. Russian proverbs]. Moscow: OLMA Media Grupp, 2011.

Mokiyenko, Nikitina 2018 - V. M. Mokiyenko, T. G. Nikitina. K kontseptsii polnogo slovarya narodnoy frazeologii: problemy makrostrukturirovaniya [The concept of a complete dictionary of popular phraseology revisited: problems of macrostructuring]. Voprosy leksikografii. 2018. No. 14. P. 80-106.

Prokosheva 1972 - K. N. Prokosheva. Materialy dlya frazeologicheskogo slovarya govorov Severnogo Prikamya [Materials for the phraseological dictionary of dialects of the Northern Kama region]. Perm: S. n., 1972.

Prokosheva 2002 - K. N. Prokosheva. Frazeologicheskiy slovar permskikh govorov [Phraseological dictionary of Perm dialects]. Perm: Perm State Pedagogical University Press, 2002. 
Stavshina 2008 (ed.) - N. A. Stavshina (ed.) Frazeologicheskiy slovar russkikh govorov Nizhney Pechory [Phraseological dictionary of Russian dialects of Lower Pechora]. V. 1-2. St. Petersburg: Nauka, 2008.

Tolstoy (ed.) 1995-2014-N. I. Tolstoy (ed.). Slavyanskiye drevnosti. Etnolingvisticheskiy slovar [Slavic antiquities. Ethnolinguistic dictionary]. V. 1-5. Moscow: Mezhdunarodnyye otnosheniya, 1995-2014. 